\title{
DIÁLOGO E CONSCIENTIZAÇÃO: COMPONDO MODOS DE FAZER SAÚDE EM TEMPOS DE PANDEMIA $^{14}$
}

DOI: http://dx.doi.org/10.18616/intcov63

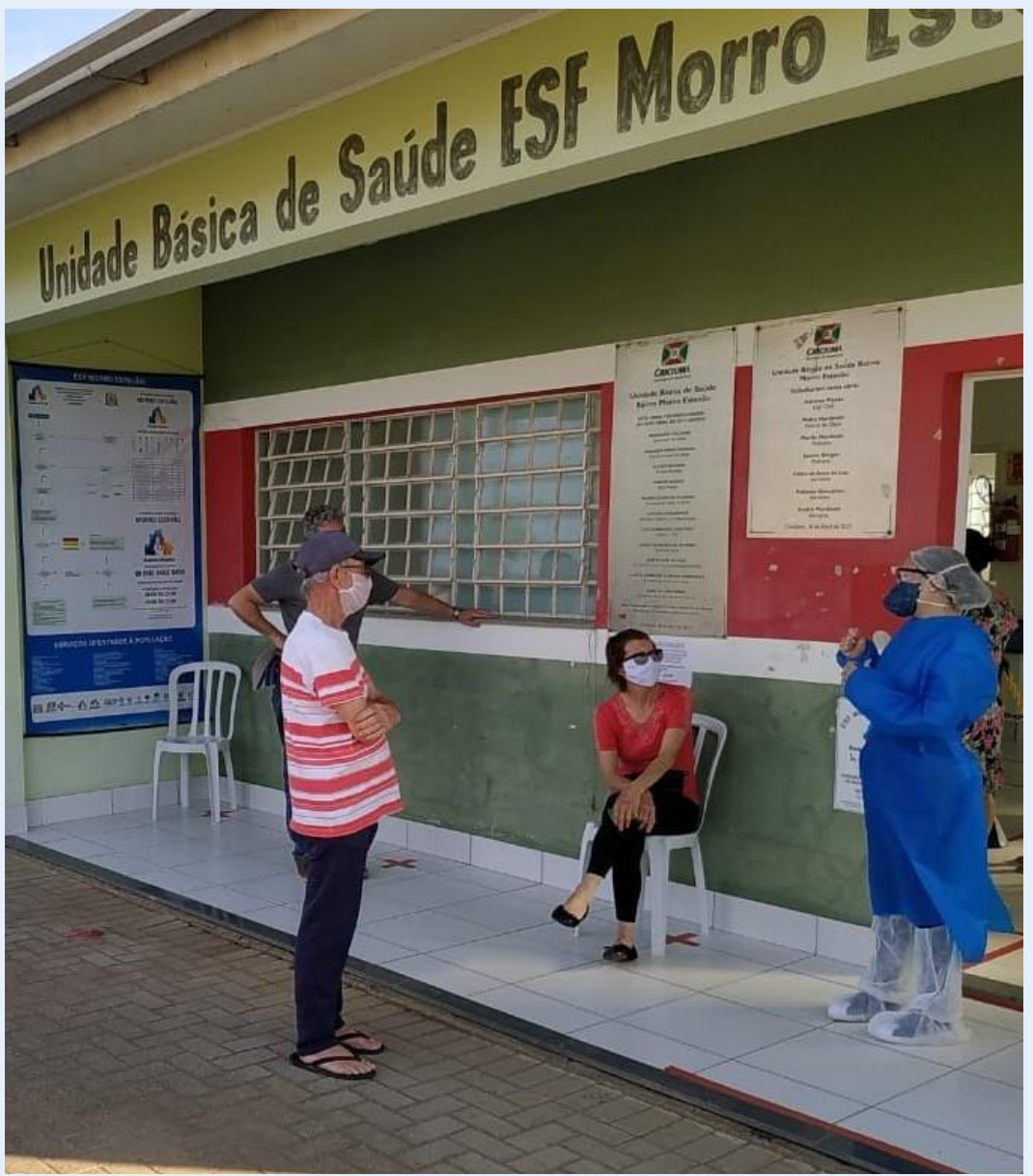

Créditos: Fernanda Nascimento D’agostin.

14 Diálogo entre a Equipe de Saúde da Família e a comunidade visando à promoção e prevenção da saúde, como ferramenta de grande importância no acesso e cuidado integral, de modo a produzir vínculo e conscientização sobre o processo de trabalho em tempos de pandemia. 